\title{
STUDIES ON Paratrigona subnuda (MOURE) (HYMENOPTERA, APIDAE, MELIPONINAE) - II. BEHAVIOUR OF THE VIRGIN QUEEN.
}

\section{VERA LÜCIA IMPERATRIZ-FONSECA}

\author{
Departamento de Zoologia Instituto de Biociências Universidade de São Paulo C.P. 20.520 \\ São Paulo - Brasil
}

\section{ABSTRACT}

The behaviour of virgin queens (Paratrigona subnuda (Moure)) was observed in about twenty colonies. The activities of these bees can be considered as a definite cycle, with the following steps: a) eclosion, b) work in the region of pots, c) occasional imprisonment in pots, seeking contact with workers, d) "settling" in the colony, e) attempts to replace the physogastric queen of the colony, f) search for a new nest. The behaviour of the gyne after replacement of the physogastric queen and during the departure of a swarm was also observed. As it happens in other species of Trigonini, the virgin queens of $P$ aratrigona subnuda undergo a phase of imprisonment inside empty pots of food. This imprisonment is considered as "voluntary" because the virgins queens leave the pots and move freely along the hive, getting into touch with the workers. The virgin queen plays a definite part in the natural replacement of the physogastric queen of the colony (supersedure), because the process of replacement is started by the virgin queen when she places a drop of a mandibular substance over the body of the physogastric queen of the colony. The possibility of existence of controlling pheromones in order to keep the physogastric queen in the colony, as well as the possible importance of pheromones in the various steps of the biological cycle of the virgin queen in the hive are also discussed in the present paper.

\section{$R E S U M O$}

O comportamento das rainhas virgens de Paratrigona subnuda (Moure) foi observado em cerca de 20 colonnias. Verificou-se que elas possuem um ciclo de atividades definido, constando de: a) eclosão, b) atividade na região dos potes, c) reclusão esporádica em potes e procura de contacto com as operárias, d) estabelecimento na colônia, e) tentativa de substituição da rainha fecundada da colônia, f) saida para um novo ninho. o comportamento após a substituição da rainha foi relatado.

Como acontece em outras espécies de Trigonini, as rainhas virgens de Paratrigona subnuda (Moure) também passam por uma fase de reclusão, utilizando potes de alimentos vazios. Essa reclusão, porém, é considerada "voluntária", pois as rainhas virgens saem dos potes e circulam livremente pela colmeia, mantendo contacto com operárias. A rainha virgen tem um papel decisivo na substituição natural da rainha fecundada da colônia, visto que o processo de substituição é iniciado com a deposição de uma gota de substância mandibular, pela rainha virgem, sobre o corpo da rainha fisogástrica da colônia. Foram

This paper is part of a Ph.D. thesis presented by the author at the University of São Paulo, with a grant-in-aid from the Fundação de Amparo à Pesquisa do Estado de São Paulo (FAPESP). 
discutidas tanto a possibilidade de um controle feromonal para a manutenção da rainha po€deira na colônia como a importância dos prováveis feromônios nas diversas etapas do ciclo biológico da rainha virgem na colmeia.

\section{INTRODUCTION}

Meliponinae are eusocial bees found in the tropical and subtropical regions in the world. They are known as "stingless bees" because they possess vestigial stings.

In Brazil, in the XXth Century, various authors such as Moure, Kerr, Nogueira-Neto, Sakagami, Cruz Landim, Zucchi and their coworkers have carried out research on the Meliponinae mainly on the following aspects: genetics, evolution, systematics, anatomy, citology, histology and ethology.

Ethology has been the subject of much research since the improvement of experimental hives (Sakagami, 1966). The processes of cell imprisonment and oviposition were carefully studied mainly by Sakagami and Zucchi in various species.

The biology of virgin queens (Vqs) is more varied in Trigonini than in Meliponini stingless bees.

The activity of virgin queens of Meliponini was observed by various authors, such as Kerr and Krause (1950); Kerr, Zucchi, Nakadaira and Butolo (1962) and Silva, Zucchi and Kerr (1972). In the Meliponini studied, the hatching of virgin queens is practically a continuous process, and the determination of castes is genetic. The permanence of a certain virgin queen $(\mathrm{Vq})$ in the colony depends on the physical condition of the physogastric queen $(Q)$, on the health of the colony and on the number of virgin queens living there. They are generally attacked by the workers (Ws), and as a result they are killed, and their heads are cut and thrown away.

In Melipona quadrifasciata, Silva et al. (op. cit.) observed the natural replacement of the fertilized queen of the colony, and also they induced non-spontaneous replacements. They found out that in the natural queen replacement (so-called "supersedure" in honeybees by Butler, 1957), a particular Vq was selected or tolerated by the Ws prior to her mother's death. In enforced queen replacement, one new queen would be chosen among others a few days after the loss of the $Q$ and would fly some days after having been accepted. In supersedure, the accepted $\mathrm{Vq}$ may join the chasing of its sister virgin queens. The cues involved in the acceptance of one $\mathrm{Vq}$ and in the rejection of another are still unknown.

In Trigonini, the biology of Vqs is more varied than in Meliponini. There are royal cells from which Vqs and even giant males can hatch. After the hatching of a $\mathrm{Vq}$ in a normal colony, the relationships between the young queen and the Ws are different in various species:

a) apparently, the Vqs can hatch without being very attractive because they do not cause any changes in the behaviour of either Ws or the $Q$ when they appear in the colony, as it happens in Paratrigona subnuda.

b) After hatching, certain Vqs are very attractive and probably eliminate volatile pheromones because an intense smell is easily detected. It was observed 
in Plebeia remota that as soon as this substance was used, it could be produced again. This odour attracts a great number of $\mathrm{Ws}$ that follow the $\mathrm{Vq}$. They begin the process of trophallaxis with the $\mathrm{Vq}$ and sometimes these oral contacts are very intense and can even seem aggresive. As certain Ws keep on oral contacts with the Vq, other Ws try to hold and keep her in any corner of the hive. Later on they build a waxen cell around her, and there she remains for some time as a prisoner. These facts were observed in Plebeia remota and in Frieseomelitta silvestrii.

The imprisonment cells were observed for the first time by Moure (1958) in Plebeia emerina. They were globe-shaped waxen cells about $1 \mathrm{~cm}$ wide, with two or three openings which allowed the $W$ to enter there to feed the Vq.

In 1962, Juliani published a paper dealing with imprisonment cells in various species, such as Trigona (Tetragonisca) jaty Smith 1863, Plebeia (Plebeia) droryana (Freese, 1900), Plebeia (Plebeia) remota Holmberg, 1903, Plebeia (Plebeia) julianii Moure, 1962 and Plebeia (Friesella) schrottkyi Friese. He verified that:

a) the $\mathrm{Vq}$ remains in prison for a variable period of time; b) the cell can present an opening or it can be closed; c) in $T$ jaty, the Ws kill the Vq spreading propolis on it (propolis can generally be found beside the chamber); d) in $P$ droryana, the chamber can be a former pot; e) in $P$. remota, the $V \mathrm{q}$ sometimes tries to rebuild the chamber when it is damaged; f) in Plebeia (Friesella) schrottkyi, the imprisoned Vqs did not cause any trouble to the Ws when they were released during the handling of the colony.

Nogueira-Neto (1963) observed that Vqs of Frieseomelitta varia can also be imprisoned. Terada (1974) observed in this species that the imprisonment cell is the territory of the young queen, and it is defended and fed by Ws of her own court.

Another kind of "imprisonment" was observed by Terada (1974) in Leurotrigona muelleri and Celetrigona longicornis: "the Vqs are kept within special borders formed by the Ws which feed the newly-born bees and that do not allow any aggresive worker or even any fertilized queen to come around" The workers on the borders are generally given the same task.

In the present paper the behaviour of Vqs in $P$ subnuda was studied.

\section{MATERIAL AND METHODS}

Twenty colonies of $P$. subnuda were studied during five years. The experimental glass-covered wooden hives, that offered good conditions of living for this species at the laboratory, were about $16 \mathrm{~cm} \times 30 \mathrm{~cm} \times 8 \mathrm{~cm}$. A lamp of $40 \mathrm{~W}$ and 220 $\mathrm{V}$ was plugged in a $110 \mathrm{~V}$ line to warm the comb area. As the bees did not build any involucrum over the comb, the physogastric queen and the comb could always be observed. A clearly defined territory was not observed, outside the hives, and several colonies could stay side by side. Swarming occurred once or twice a year, so that all the biological cycle related to this species could be studied.

The method used was that of direct observation. The bees were marked with coloured nitrocellulose paint. Colonies were designated by boldface capitals. 
In this paper the physogastric queen will be called $\mathrm{Q}$, the virgins queen $\mathrm{Vq}$ and the workers Ws.

\section{RESULTS}

The Vqs hatch all over the year. Sometimes some Vqs are found walking in the colony, chiefly in swarming periods. Their behaviour and the time they remain in the colony depend on some factors, such as the general health of the colony, the number of Vqs present and season of the year. The attraction of each queen has a great individual variability.

The different kinds of behaviour during the life cycle of the Vqs of Paratrigona subnuda can be divided into phases, such as: hatching, walking in the region of honey and pollen pots, occasional imprisonment in pots, search for contacts with workers, "settling" of the $\mathrm{Vq}$ in the colony, substitution of the physogastric queen of the colony and behaviour of the Vq during the swarming.

\section{PHASE 1: Hatching}

The new queen hatches with a light tegument that darkens day after day. She is not attractive, and moves slowly in the comb region. She alway cleans herself, and the workers do not encircle her.

The beginning of the attraction varies individually and according to the conditions of the colony. The $\mathrm{Vq}$ moves rapidly in the colony, seeks contacts and trophallaxis with workers, visits empty pots. Her excretions sometimes are eaten by the workers. Some workers grasp on her abdomen but leave her afterwards.

\section{PHASE II: Activity in the region of pots}

The $\mathrm{Vq}$ works sometimes with the cerumen in several ways such as: a) work in the involucrum, b) building of pillars, c) opening and shutting of pots, d) covering of cells after operculation, e) working on deposits of pure wax. She is sometimes among the Ws in the "court" done by them to any worker egg in a brood cell.

The Vqs spend great part of their time in the region of pots. In this species, the pots are built and closed only when full of food (nectar or pollen). On the other hand, some empty closed pots could be found among other pots. In 1973, a Vq was seen when she was opening one of these pots and coming out of it. The Ws around the pots were not disturbed by her presence. She walked in the colony, returned to the empty pot and shut it with cerumen. Then, she could remain there without being disturbed.

The "queen pot" has the upper end built in a different way. Sometimes the antennae of the $\mathrm{Vq}$ can be seen passing through the cover of the pot. It is possible that behaving like that the $\mathrm{Vq}$ receives the chemical changes of the surroundings. It is interesting to observe that the $\mathrm{Vq}$ comes out of the pot when a situation of alarm occurs near the pot, even if her antennae are inside the pot.

Initially, the Vq goes alone into the pot and shuts it without difficulty. She stays there according to the activity of the colony and the phase of her life cycle.

The relationship between the $\mathrm{Vq}$ and $\mathrm{Ws}$ is not remarkable at the beginning. The Vq goes to the comb region and to the involucrum, and the Ws do not to 
pay attention to her. She walks in the colony, and the Ws generally leave her alone. Trophallaxis between $\mathrm{Vq}$ and $\mathrm{Ws}$ are seldom observed.

During the observations, it was seen in col. $Q$ a Vq that cut the basis of a honey pot, and through the slit it became empty; Ws that were nearby ate the honey, and tried to repair the pot. The Vq came again to cut the basis of the pot. Later on, the honey pot was empty, and one $\mathrm{Vq}$ visited it. Maybe this is the method to get an empty pot. Some bees put loads of pollen into the "queen pot" for it is a source of protein to the Vq.

If Ws are going to use the "queen pot" for storage, they put some cerumen outside it. The $\mathrm{Vq}$ then can walk along the colony or even stay hidden under the detritus storage area.

PHASE III: The Virgin queen seeks contacts with the workers

Evidence of the beginning of this phase is observed by the attractiveness of the Vq to the Ws that try to grasp her tergites, and sometimes to bite them. The $\mathrm{Vq}$ comes near one worker, and seeks for some trophallaxis. There are exchanges of substances, and often the $\mathrm{Vq}$ delivers a drop over that worker, which becomes very attractive. Then, this worker will be licked by the other bees around her. The workers behave as if the worker that received a drop of "royal substance" were a queen. A similar fact was demonstrated in the film "Pouvoir d'attraction de la reine d'Abeille", made by the C.N.R.S., in France, on the pheromones of Apis mellifera studied by J. Pain. One worker wa covered by the "queen substance", and the others licked her as if she were a queen.

The Vq's visits to the pots are frequent, but they do not remain a long time there. Some Ws generally are around the pot, or even inside it, with the $Q$. Other bees can mark the queen pot, or open it from the outside (in most occasions, the $\mathrm{Vq}$ herself opens the pot).

In this phase it is common to find the Vq's pot opened, and she remains there with her head and torax outside, and her abdomen inside the pot. She can stay in this position for almost one hour keeping close contacts with Ws mainly by having much strong trophallaxis and antennae contacts. With these contacts the $\mathrm{Vq}$ soon acquires a court of Ws that also feed her. It is very important to the colony aggregation to observe that these relationships between $\mathrm{Vq}$ and $\mathrm{Ws}$ belong to the life cycle of the $\mathrm{Vq}$, and are reinforced when there are many Vqs in the colony. In that way, a lot of Ws of the colony follow the Vqs and do not accomplish the normal tasks according to their age. In this phase they are often seen being attacked by other workers of the same colony, and these workers possibly follow different Vqs. The workers eat the Vqs feces.

Ihrough a pot constructed near the hive glass, it was seen that the $\mathrm{Vq}$ remains inside the closed pot, without moving her wings. She can be accompanied or not by workers, and seldom works with cerumen in the pot, so the inner surface looks velvetlike.

Some examples of the time spent by the $\mathrm{Vq}$ to open her pot: $3 \mathrm{~min} ; 14$ $\min$; $40 \mathrm{~min} ; 13 \mathrm{~min} ; 10 \mathrm{~min} ; 7 \mathrm{~min} ; 9 \mathrm{~min} ; 5 \mathrm{~min} ; 12 \mathrm{~min} ; 25 \mathrm{~min}$. The different values obtained can be explained by different phases of the Vq's biological cycle. 


\section{PHASE IV: Settling of virgin queens in the colony.}

This phase begins when the $\mathrm{Vq}$ becomes very attractive. Many Ws are seen around her "pot" and if it is closed, they can open it in order to seek some contacts with the Vq. This opening sometimes is so sudden that it damages the pot. The main contact is the "strong trophallaxis" that is, a trophallaxis in which the first pair of the $\mathrm{Vq}^{\prime}$ 's legs reaches the face of the $\mathrm{W}$; it seems that the $\mathrm{Vq}$ and the $\mathrm{W}$ bite the mandibles of each other. Then, it is possible that the $\mathrm{Vq}$ releases her royal substance over the W's body.

The $\mathrm{Vq}$ is always seen with a court of Ws; she prefers to stay in some definite places in the colony, such as part of the pot region, or the involucrum, the detritus area, etc. When she is very excited, she behaves differently and that attitude can be called the settling of the $\mathrm{Vq}$ in the colony. It is characterized by an increase of her abdomen volume, mainly in the last terga, and by movements in a circle the center of which is near her head. At this time the $\mathrm{Vq}$ is licked by the Ws, mainly at the end of the abdomen. She has a large court and the encircling Ws try to touch the last segments of her abdomen with the antennae. Generally, the Ws have first an attitude of attack in relation to the abdomen of the $\mathrm{Vq}$; the workers' mandibles are opened. After this contact, they can look for a "strong trophallaxis" with the queen. In colony $F$ it was verified (March $26,73)$ that the Vq delivered a special odour in a "strong trophallaxis" a fact that suggests the presence of special pheromones in this contact.

The "settling" phase varies according to the kind of contacts between the Vq and the Ws to the general condition of the colony, to the activity of the $\mathrm{Q}$, etc. Many Ws that encircle the $\mathrm{Vq}$ try to lick her, but others (that possibly are part of other queen's court) attack her strongly. The Vq runs over the colony moving her wings, seeks trophallaxis, and then stops near the workers. If she is actually attacked, she comes back to a pot, enters there, closes it and remains inside the pot.

The steps of settling are carried out little by little, and can be repetead many times before the $\mathrm{Vq}$ reaches her climax: she tries to leave the colony with a swarm to form a new nest, or even tries to substitute the $Q$ of the colony.

Some "settling" attitudes can also be observed after the laying queen's supersedure, at the moment the $\mathrm{Vq}$ nuptial flight is going to occur.

PHASE v: Substitution of the physogastric queen of the colony

The various steps of the $\mathrm{Vq}$ establishment in the colony disturb the Ws, and even some newly-born Ws participate in the $\mathrm{V}_{4}$ court. When the establishment is at its climax, the $\mathrm{Vq}$ is very excited and with rapid movements and wing vibrations moves towards the $\mathrm{Q}$. The $\mathrm{Vq}$ lets a drop of a buccal substance fall over her body (generally over the abdomen). Imediately after this, the number of Ws that encircle the $Q$ increases, and they lick the region near the drop. Generally the $Q$ does not react, staying quiet and performing only toilet movements. At this time the $\mathrm{Vq}$ runs throughout the hive, seeking rapid and strong contacts with the workers. Some of them attack her. The visits of the Vq to the Q's body become more frequent, with several depositions of the $\mathrm{Vq}$ excretions over the Q's body. It can be observed that: a) the $\mathrm{Vq}$, during her attempts to "set up" in a colony as a queen, can be attacked, probably by workers that encircle the $Q$, and those 
Ws hold her in order to kill her later; b) the Vq's excretions (oral and also fecal) are more and more frequent, until the $Q$ is attacked by the Ws that licked her, and then killed and cut into pieces. It is very interesting to observe that this process of the Q's substitution is developed as a part of the biological cycle of the $\mathrm{Vq}$, notwithstanding the physiologic activity of the $\mathrm{Q}$ and the general conditions of the colony. Nevertheless, when the $Q$ is very productive and the colony is strong, seldom the $\mathrm{Vq}$ can substitute the $\mathrm{Q}$.

The $\mathrm{Vq}$ that tries to substitute the $Q$ is not always the oldest one. The development of the Vq's biological cycle has a great individual variation. The other Vqs that may exist in the colony do not disturb the Vq that "sets up"; they remain hidden in the pots, seeking contacts with workers, etc. (for instance, in colony $Q$, the Vq-2 tried to substitute for the $Q$ when Vq-1 walked normally in the colony, trying to hide herself in a pot).

Ws licking the $Q$ or the Vq's last terga were observed many times. But it is important to point out that this kind of licking and courting is very different from that observed in the $Q$ substitution, when the whole of the Q's body is licked and receives a great amount of the special substance delivered by the Vq. The Ws that encircle the $Q$ during the process of substitution seem more active. As the process goes on, the $\mathrm{Vq}$ visits to the $\mathrm{Q}$ 's body become more frequent and there is an increase of the Vq's excretions over the $Q$ and also some excitement. When the Vq excrets over the Q's body, a larger number of Ws encircle the $Q$. At this time, it was also observed that some Ws were over the Q's body.

\section{PHASE VI: Activity of the $V q$ after the $Q$ 's substitution}

In the process of substitution, it is necessary that the $\mathrm{Vq}$ spends a lot of energy, partly recovered with the help of frequent trophallaxis. After the elimination of the $\mathrm{Q}$, the $\mathrm{Vq}$ rests somewhere in the colony; it was not observed if she remains inside any pot after the $Q$ substitution. She can be seen occasionally in the comb region, sometimes "settling up" attitudes. When she swells her abdomen, a white spot between the second and third terga is seen and it is characteristic of the attraction phase.

Sometimes the $\mathrm{Vq}^{\prime} \mathrm{s}$ abdomen is normal, and she does not seem specially attractive. The swelling of the abdomen of the substituted $\mathrm{Vq}$ before her nuptial flight increases gradually. The substitution of the $Q$ by a $V q$ does not mean that this $\mathrm{Vq}$ will be fertilized. In a colony many Vqs can be found, and they may be in the same biological cycle. The attractiveness of the Vqs may not be controlled by the $Q$, and several of them can be at the same phase. At this pont, generally one of them is dominant.

It was also observed that another $\mathrm{Vq}$ (not the one that substituted the $\mathrm{Q}$ ) may also have a nuptial flight.

\section{Nuptial flight}

In colony $I$ (November 30,1973 ) the nuptial flight occurred three days after the $\mathrm{Q}$ substitution. The $\mathrm{Vq}$ was attractive to the males, at $2: 18 \mathrm{pm}$. She was very excited, seeking contacts with workers, and moving rapidly along the colony. At 4:05 pm she went out through the main entrance of the colony, and had a flight, probably the nuptial one. Males were not observed on the outskirts of the 
colony. At 4:32 pm she returned to the colony: she did not go immediately into the entrance canal, but stayed nearby. At $4: 37 \mathrm{pm}$ she was inside the main entrance of the colony, and at $4: 39 \mathrm{pm}$ she was over the comb region.

She was especially attractive: anywhere she passed, the males tried to fertilize her. Sometimes she stopped at the comb region, cleaned hel head, and seeked trophallaxis. She avoided the lighted sites of the observation hive, where the males were more active. They were attacked by the workers, when they disturbed the queen. In good colony conditions, the interval between the Q's substitution and the beginning of both normal cell construction and oviposition by the new queen is one week.

If some alarm situation occurs in the colony, the males also try to copulate with the queen, even is she is not yet ovipositing.

The sporadic construction of brood cells continue even during the maturation of the newly fertilized queen. At this time, the new $Q$ can excrete in the involucrum or over the comb, and her feces are eaten by the Ws. Seldom some bees grasp her abdomen, or even lick her genital chamber, when this part of the Q's body is rubbed by herself (this attitude also attracts some males, that are then attacked by the workers).

\section{Virgin queens and swarm}

In swarm time, once 6 Vqs or more were found in the colony. During 5 days the external movement was remarkable. In the 6th day, transportation of materials from this colony was observed. Many Vqs were active in the colony. At the back region, near the main entrance of the hive, there were many workers, and the Vqs were often seen. At 11:50 a m, at $27^{\circ} \mathrm{C}$, (this temperature is considered as good), a swarm left the colony: a lot of workers followed the most attractive $\mathrm{Vq}$; another group of $\mathrm{Ws}$ and an attractive $\mathrm{Vq}$ followed by $\mathrm{Ws}$; a third $\mathrm{Vq}$ was also followed by Ws. Inside the colony and also outside, at the main entrance, there were no groups of males; they should probably be near the new nest.

\section{DISCUSSION}

\section{Hatching and Attractiveness}

Studies on Apis mellifera carried out by Pain (1959) showed a lack of attractiveness in Vqs when they hatch. Afterwards the attractiveness is directly related to the number of workers that follow the $\mathrm{Vq}$, to such an extent that her development is more rapid than usual when she is followed by a higher number of Ws. The power of attraction, however, varies from one queen to anothen; some Vqs show their attractiveness since the second day after hatching, although the majority of Vqs are attractive from the third day onwards.

Pain, Hugel and Barbier (1960) observed that the recently hatched Vqs released a reduced amount of royal substance. Butler and Panton (1962) found out that the amount of this substance released by the Vqs increased very quickly during their first week of life and remained abundant until old age. Through chromatography, Butler and Panton (1962) showed the following amounts of royal substance: $7,70 \mu \mathrm{g}$ in one-day and two-day-old Vqs; $132,50 \mu \mathrm{g}$ in five-day to 
ten-day-old Vqs; $149,62 \mu \mathrm{g}$ in the three-week to six-week Q. The Qs release a higher amount of royal substance, mainly at oviposition periods.

The recently-hatched Vqs of $P$. subnuda can be more or less attractive, depending on their individual characteristics. The beginning of their attractiveness is closely related to the conditions of the colony. It is also possible that some queens present a stronger power of attraction when compared to others, because the stronger ones can settle more rapidly than the others. After a comparison between $\mathrm{Vq}-1$ and Vq-2 from colony $Q$ in March 1974, and between Vq-2 and Vq-3 queens from colony $J$ in January 1973, we observed that the youngest queens settled sooner.

Among Meliponini, active Vqs can be seen soon after hatching. Silva et al. (1972) pointed out that "the Vqs of Melipona quadrifasciata anthidioides move rapidly and easily, and look immediately for hiding-places under pots and combs, since their hatching" As it was said in the Introduction of this paper, the Vqs of 'Trigonini can either be very attractive soon after hatching (as, for instance, in Plebeia, Frieseomelitta) or show a period "maturation", as it happens to Paratrigona.

\section{Activity of a virgin queen in the colony}

The behaviour of Vqs of Plebeia in the imprisonment cells was observed in $P$. remota by Imperatriz-Fonseca et al. (1975), and also in $P$ droryana by Cortopassi and Imperatriz-Fonseca (unpublished paper). In $P$. remota, the $\mathrm{Vq}$ deals easily with wax in the imprisonment cell. The Ws which stay around the chamber enter there through a small opening only to feed the Vq. The expulsion of workers from the cell as well as the closing of the opening hole are done by the $\mathrm{Vq}$ herself. The imprisonment would be helpful, because the cell acts as a physical barrier, and the $\mathrm{Vq}$ could maintain or not her contacts with workers through opening or closing the cell. In Plebeia droryana, the imprisoned $\mathrm{Vq}$ may remain shut inside the cell during the first days. In the next step, the $\mathrm{Vq}$ opens the cell quite often, and the imprisonment cell becomes quite different because of the great amount of pure wax placed on the chamber. The Vq continues to be in touch with Ws and this process reaches a climax when the $\mathrm{Vq}$ leaves the imprisonment cell and walks freely along the colony, generally followed by a group of Ws. It is worthwhile to point out that the power of attraction varies from one $\mathrm{Vq}$ to another; in fact, it was observed that one of them left the imprisonment cell before some pure wax was placed on her chamber. The activity of $\mathrm{a} \mathrm{Vq}$ is also influenced by the colony conditions. For instance, there is a change when the colony suddenly becomes orphan. The active $\mathrm{Vq}$ of the colony is able to substitute the physogastric queen, although sometimes this fact does not occur. According to Silva (1972), this $\mathrm{Vq}$ could be fertilized even in the presence of the oldest physogastric one; in a normal colony two egg-laying queens were found, one being older than another. The younger $Q$ laid eggs more often than the older.

The following items are concerned with the behaviour of Vqs of Paratrigona:

a) the pot in which the $\mathrm{Vq}$ hides can be considered as a territory when it is closed;

b) we observed that the same pot can be used by more than one $\mathrm{Vq}$, one after the other; 
c) after reaching a certain degree of attractiveness, the Vq seems to "prefer" to hide in certain pots;

d) when the $\mathrm{Vq}$ remains near the pot-opening and from there it gets into touch with Ws, it occupies an area which can be called "home range";

e) we observed quite often that, in colony $P$, the main $\mathrm{Vq}$, which was in an open pot, caused a reaction of "leaving the territory" when another Vq came near. In this case, the concept of Noble (1939) about a "defense area" can be applied. There was also a relationship between dominance and territory;

f) the Vqs of the colony are seen quite often in the region of waste matter and dark areas, where they can rest; this area can be considered as a part of their "home range";

g) the active Vqs generally do not remain at the comb region where they are pushed by workers of by the $Q$ itself. The brood comb can be considered as the territory of the laying queen of the colony, because she stays mainly in that region, from where the attractive $\mathrm{Vq}$ are repulsed;

h) there was a certain area of settling in the hive where the $\mathrm{Vq}$ always tried to be in contact with Ws. We observed, for instance, in colony $F$, that this area was near the place preferred by the $Q$, and this fact turned the substitution easier. Even during substitution, the Vq came back to the "settling area" where it behaved differently. This area could be considered as a division of the "territory" of the active Vq, similar to that found by Hediger (1955) in mammals. In a particular situation, concerning the $\mathrm{Vq}$ number 37 from colony $l$, this area was the same where the pot chosen by the $\mathrm{Vq}$ was built;

i) from the hatching to the settling in the colony, the $\mathrm{Vq}$ of Paratrigona subnuda lives in different areas, in a process called "home range" until it comes to a territory. This area is defended by the workers that encircle the Vq. The workers often touch the Vq's body with their antennae and they even eat her waste matter. In the region of her own pot, the $\mathrm{Vq}$ is seldom attacked; if any attack occurs, she tries to enter into any available pot. It was often observed that the $Q$ was taken away by Ws that were working in the region of pots where the attractive $\mathrm{Vq}$ remained. These $\mathrm{Ws}$ were constantly seen working in that region.

In Paratrigona subnuda, the problem of territories should be discussed. In normal conditions, the $Q$ remains in the brood comb, which is her main territory. When she walks along the hive, she comes back to the comb very quickly. The $Q$ also leaves the region of brood combs when there are several Vqs in the colony. At this time she goes to any part of the involucrum of the colony or even to the region of pots. She leaves the region of combs mainly when there are problems of productivity related to her physical condition or to activities of Ws related to swarming. After the colony recovers its normal conditions, the $Q$ comes back to the comb as her main territory, and then the attractive $\mathrm{Vq}$ are taken away by the Ws;

j) the number of Vqs in the colony also influences their activities. In colony $P$, where there were five $V \cdot s$ at the same time, the dominance was related to 
attractiveness. The $\mathrm{Q}$ of the colony was in good conditions and was not replaced. The dominant $\mathrm{Vq}$ of the colony was not always the same. The dominance was determined by the relationships between $\mathrm{Vq}$ and $\mathrm{Ws}$, number of trophallaxis and activity in the regions of pots. A relation between dominance and territory was observed.

Comparing the number of Ws that were part of the court of the $Q$ with the number of Ws that were part of the court to a Vq trying to "set up", it was seen that the latter presented peaks of attraction. The "setting up" of the Vq in the colony is carried out step by step, and its beginning was seen by the trophallaxis in the "home range" of the Vq. The next step would be the standing of the Vq at the opening of the pot. Afterwards the "setting up" itself is seen, when the $\mathrm{Vq}$ inflates her abdomen and attracts some Ws, that lick the end of her abdomen (last tergites). This final step of "setting up" sometimes takes several days, and movements and attractiveness seem to increase. Finally, the Vq would try to swarm of to substitute the $Q$ queen. This phase is then irreversible.

Then:

$$
\begin{aligned}
\text { Fs }=S_{1}+S_{2}+\quad+S_{n}, & \text { where } \\
& F S=\text { final setting up } \\
& S_{1}=\text { first phase of setting up } \\
& S_{2}=\text { second phase of setting up } \\
& S_{n}=n^{\text {th }} \text { phase of setting up }
\end{aligned}
$$

The attractiveness of $\mathrm{Vq}$ might be related to the group of Ws that court her. For instance, a Vq that released substances on the $\mathrm{Q}$ in her colony was transferred to another colony that was swarming. The $Q$ of the second colony was not very productive, and there were many royal cells being built. The Vq immediately excreted on the $Q$ body, continuing the process that had already begun. The Vq, however, did not substitute the $Q$, probably because of lack of former contacts with the Ws of the colony.

The study of division of work among Ws was done at this laboratory in $P$. subnuda (unpublished paper). The bees that were building brood cells were also courting the $Q$ of the colony. Some of them were layers, and they put some larval food into the brood cells and operculated them. At the same age, some Ws encircled the Vq. When there were many Vqs in the colony, one-day-old workers were seen working in Vq's pots. This fact explains partly a decrease in the productivity of the $Q$ during swarming. The Vqs try to "set up" and to form territories, probably by spreading their pheromones on the Ws that encircle them.

In this way, walking along the hive and near the openings of the pots, they search for trophallaxis with the largest possible number of Ws. There is an increase in attractiveness of $\mathrm{Vq}$ in the colony. It is normal then that a smaller number of Ws court the $\mathrm{Q}$ of the colony, and also build new brood cells.

The productivity of the $Q$ is related to the number of bees in the hive. When there are several Vqs in the colony, and if there is a swarm. a kind of 
"social rupture" is felt. Then, the division of work which is basically important to keep the social structure of the colony, undergoes several changes, and the colony turns very weak and may even die.

Considering the consequences of the activity of Vqs on the population of the colony, the appearance of giant males stands out. In colony $E$, for instance, from Oct. 5, 1972 to March 29. 1973, 14 royal cells were built. From Sept. 29, 1972 to April 16, 1973 five giant males and $6 \mathrm{Vq}$ were seen in the colony. Giant males hatch from royal cells and their activities are similar to ordinary males (Imperatiz-Fonseca, 1976).

The relationships between the probable royal substances produced by the $Q$ and the building of royal cells remain still unknown. Royal cells can be built together with other cells from the batch, without being the target of the $Q$. Sometimes, the $Q$ seems very excited toward oviposition in the royal cell. If the $\mathrm{Q}$ does not come near the royal cell during this process, the cell is closed with the egg laid by a W. During some oviposition processes, only the royal cell can be built; sometimes, two royal cells are constructed in one day, even in the same process of building. This problem is still under investigation. It can be said, however, that royal cells are built mainly when: a) the population density is high; b) there is no building of brood cells, in the processes after swarming: c) in cases of orphanhood.

\section{Queen's excretions in the Meliponinae}

In the Meliponinae Ws and male bees excrete in some definite places of the colony, so-called waste matter deposits. The $\mathrm{Q}$, however, does not use those deposits and excrete anywhere in the hive.

Silva, Zucchi and Kerr (1972:130) referred to the feces of Qs from Scaptotrigona postica, Axestotrigona ferruginea tescorum, Melipona quadrifasciata, etc. Those feces are eaten by the Ws. The authors concluded that this fact might be important for the social regulation of the colonies in Meliponinae. However, they observed that the feces of $\mathrm{Vq}$ were not eaten bv Ws

In Paratrigona the Vq excrete mainly when they are particularly active. Then, their feces are eaten by the Ws which encircle them. The most important fact is observed when the $\mathrm{Vq}$ which tries to substitute the $\mathrm{Q}$ of the colony eliminates some fecal and oral substances on the Q's body. This procedure should confirm the hypothesis that the excretions act as pheromones. The oral substances of $\mathrm{Vq}$ seem to be the most important. It was observed that the active Vqs excrete oral substances even on the pots belonging to other $\mathrm{Vq}$, and afterwards this matter is eaten by the Ws that encircle the pot. This way, the Vq would spread her pheromones among the Ws. Mandibular glands of $\mathrm{Q}$ in Paratrigona are remarkably developed, and it is possible that the oral substances are mainly of mandibular origin.

Velthuis (1970) observed that in Apis there was an important abdominal gland for the social regulation of the colony, the dermal glands described by Renner and Baumann (1964) in tergites II - IV). If the mandibular glands of the $Q$ of the colony are removed, she still behaves as the colony $Q$, making it difficult to build royal cells and blocking the development of W's ovaries. It is possible 
that in Paratrigona there is also a release of pheromones through the abdominal region. The mandibular glands, however. are also important, mainly for the natural replacement of the $Q$.

Another kind of excretion observed in the $\mathrm{Q}$ comes from the mandibles. It is not very common and is released in the region of brood combs by the $Q$. She can drop the substance on the glass, and that drop probably contains a suspension of the material. Silva et al. (1972) observed that the substituted queen of some species of Meliponini, when are not being fed, throw up from their mouths a drop which is offered to the Ws of their courts. The Ws then begin to feed the queen immediately. This behaviour was observed before and after the nuptial flight but it would not be verified some time after they began to lay eggs.

Simōes (1974) observed a Vq of Scaptotrigona postica running along on the glass of a hive, where she put an yellowed substance from her mandible. Ws ate this substance. This fact suggested the presence of a pheromone control by the Vq.

\section{Swarming}

Among other facts, it is interesting to point out the departure of the swarming, when more than one $\mathrm{Vq}$ (about three, in our observation) go to the new nest. The colony undergoing swarming generally does not have nearby a lot of males; they are probably near the new nest. The first Vq to leave seems to be the most attractive. It is still unknown whether the process of fertilization occurs at the entrance of the new nest or in the daughter-colony itself. In the available information about swarming in Meliponini (Nogueira-Neto, 1948; Terada, 1972: Schwarz, 1948) there are not data on more than one $Q$. leaving together in the swarm process.

The activity of imprisoned Vq's in cells overrested by physical barriers, in other Trigonini, does not contradict the possibility of a multiple $\mathrm{Vq}$ flight, or even the chance that they remain in the new colony after leaving the mother colony. On this matter, Paratrigona subnuda would be considered as more primitive than the above-mentioned bees, because free Vqs which possess a certain degree of rominance are found in Bombinae (Zucchi, 1974).

\section{ACKNOWLEGEMENT}

My best thanks to Dr. Paulo Nogueira Neto for advice and help during the elaboration of my $\mathrm{Ph}$. D. thesis.

\section{REFERENCES}

BUTLER, C. G., 1957. The process of queen supersedure in colonies of honeybees (Apis mellifera). Insectes Sociaux, 4 (3): 211-223.

BUTLER, C. G. and P. N. PANTON, 1962 - The source of the queens substance of the honey bee (Apis mellifera L.). Proc. R. Entom. Soc. Lond. Ser. A, 37: 114-116.

HEDIGER, H., 1955 - Psycology of Animals in Zoos and Circuses Butterworths Sc. Publ. London, 166 pp.

IMPERATRIZ-FONSECA, V. L., 1975 - Estudos bionômicos sobre a rainha virgem de Paratrigona subnuda (Moure) (Apidae, Meliponinae) Ph.D. Thesis presented to the Instituto de Biociéncias, Universidade de São Paulo. 
IMPERATRIZ-FONSECA. V. L., 1976 - Studies on Paratrigona subnuda (Moure) I: Members of the colony - Rev. Bras. Ent. 20 (2): 101-112.

IMPERATRIZ-FONSECA. V. L., M. A. C. de OLIVEIRA \& S. IWAMA, 1975 - Notas sobre comportamento de Plebeia (Plebeia) remota Holmberg (Apidae, Meliponinae). Cienc. $e$ Cult., 27 (6): 665-669.

JULIANI, L., 1962 - O aprisionamento de rainhas em colônias de Trigonini. Bol. Univ. Parand, 20: 1-11.

KERR, W. E., and W. KRAUSE, 1950 - Contribuição para o conhecimento da bionomia dos Meliponini. Fecundação da rainha de Melipona quadrifasciata Lep. (Hymenop. Apoidea). Dusenia 1 (5): 275-282.

KERR, W. E., R. ZUCCHI, J. T. NAKADAIRA e J. E. BUTOLO, 1972 - Reproduction in the social bees (Hymenoptera, Apidae). J. N. Y. Ent. Soc., 70: 265-276.

MOURE, J. S., P. NOGUEIRA-NETO and W. E. KERR, 1958 - Evolutionary problems among Meliponinae. Proc. Tenth International Congress of Entomology, 2: 481-491.

NOBLE, G. K., 1939 - The role of dominance in the social life of birds. Auk. 56: 263-273.

NOGUEIRA-NETO, P., 1963 - Novas pesquisas sobre os Meliponíneos. Chac. e Quintais, 108 (6): $690-691$.

PAIN, J., 1959 - tude de l'apparition de l'attractivé chez reines vierges de l'abeille. $C$. R. Acad. Sci. (Paris) 218: 3211-3212.

PAIN, J., M. F. HUGEL and M. BARBIER, 1963 - Sur les constituants du mélange attractive des glandes mandibulares des reines d'abeilles (Apis mellifera L.) à différents stades de leur vie. C. R. Acad. Sci. (Paris), 256: 512-515.

RENNER, M., and M. BAUMANN, 1964 - Uber Komplexe von subepidermalen Drusenzellen (Duftdrusen) der Bienenkonigin. Die Naturwissenschaften, 51 (3): 68-69.

SAKAGAMI, S. F., 1966 - Techniques for the observation of behavior and social organization of stingless bees by using a special hive. Papéis Avulsos Depto. Zool. Secret. Agric. S.P., 19: 151-162.

SILVA, D. L. N., 1972 - Consideraçōes em torno de um caso de substituição de rainha em Plebeia (Plebeia) droryana (Friese, 1900) (Hymenoptera, Apidae) - In: Homenagem a W. E. Kerr por ocasião do seu 509 aniversário - Rín Claro, p. 287-293.

SILVA, D. L. N., 1973 - Estudos bionômicos em colônias mistas de Meliponinae (Hymenoptera, Apidae) 114 p. Ph. D Thesis presented to the Fac. Fil. Cienc. e Letras de Ribeirăo Preto.

SILVA, D. L. N., R. ZUCCHI \& W. E. KERR, 1972 - Biological and behavioural aspects if the reproduction in some species of Melipona (Hymenoptera, Apidae, Meliponinae). An. Behav., 20 (1): 123-132

SCHWARZ, H. F., 1948 - Stingless bees (Meliponinae) of the western hemisphere - Bull. Amer. Mus. Nat. Hist., 90: 1-546.

SIMÓES, D., 1974 - Estudos sobre a regulação social em Nannotrigona (Scaptotrigona) postica Latreille, com especial referência a aspectos comportamentais (Hymenoptera. Apidae, Meliponinae). M. Sc. Thesis - presented to the Faculdade de Medicina de Ribeirão Preto, Universidade de São Paulo.

TERADA, Y., 1972 - Enxameagem em Frieseomelitta varia Lep. (Hymenoptera, Apidae). In: Homenagem a W. E. Kerra, por ocasião de neu 50 aniversário. Río Claro, 1972.

TERADA, Y., 1974 - Contribuição ao estudo da regulação social em Leurotrigona muelleri e Frieseomelitta varia (Hymenoptera, Apidae) $M$. Sc. Thesis - presented to the Faculdade de Medicina de Ribeirão Preto, Universidade de São Paulo.

VELTHUIS, H. H. W., 1970 - Queen substances from the abdomen of honeybees queen. Z. vergl. Physiologie, 70: 210-222.

ZUCCHI, R., 1973 - Aspectos bionômicos de Exomalopsis aureo pilosa e Bombus atratus incluindo observaçōes sobre a evolução do comportamento social (Hymenoptera, Apoidea). - Ph. D. Thesis presented to the Fac. Fil. Cienc. Letras de Ribeirão Preto, Universidade de São Paulo. 